\title{
Range condition analysis: Comparison of 2 methods in southern New Mexico desert grasslands
}

\author{
E. TEDONKENG PAMO, REX D. PIEPER, AND RELDON F. BECK
}

\begin{abstract}
Interest in evaluating theoretical considerations in traditional methods of determining range condition have increased recently with application of different analytical techniques. In this study, the traditional quantitative climax approach was compared to a cluster analysis method on range sites in desert grassland in southern New Mexico. Both methods identified 3 classes that corresponded to successional stages or range condition classes. The cluster analysis approach provided a more precise procedure than the quantitative climax approach, as evaluated by multiple discriminate analysis. However, the cluster analysis is a much more complex analytical procedure than the quantitative climax approach, and may be limited for management purposes.
\end{abstract}

Key Words: secondary succession, spatial variation, cluster analysis

Rangelands are characterized by large variations in time and space. Classification of rangelands into sites, habitat types, or some other unit of landscape is an attempt to deal with spatial variation. Range condition classification attempts to deal with temporal variation on 1 range site or habitat type. Problems arising from these 2 types of variation have many similarities, but are often addressed in separate steps.

Range condition classifications have been handled mainly from 2 approaches (Hacker 1983, Smith 1979). The site-potential approach (Humphrey 1947, 1949) rates the present productivity of a site in relation to the maximum potential for that site. This approach involves a separate rating for each use. An ecological approach rates present vegetation to that under climax or near climax conditions (Dyksterhuis 1949, 1968). Such an approach should be independent of intended uses for the land, but Smith (1979) detected biases in the way the method has been applied in the United States toward cattle grazing.

As managers view rangelands, they see only the present vegetation and are immediately faced with the problem of separating different sites with different successional patterns from those with similar successional patterns but presently in different successional stages. Several papers have dealt with the problem of multiple seral stages that overlap but represent 2 or more distinct climaxes (Huschle and Hironaka 1980, Nieman and Hironaka 1989). Others have dealt with approaches for differentiating range sites or habitat types (Anderson 1963, Daubenmire 1984, Dyksterhuis 1985, Hall 1985, Hoffman 1984, Meeker and Merkel 1984). The importance of range condition analyses is attested to by the publication of a symposium on the subject in 1989 (Lauenroth and Laycock 1989).

Several methods are available for classifying range vegetation (Bonham 1983, Ratliff and Pieper 1982). However, these approaches do not address the problem of confounding successional differences with site differences. Consequently, this paper will address only successional changes on specific range sites.

Several approaches, illustrating different levels of analytical sophistication, have been used to classify ranges into different condition classes (Tueller and Blackburn 1974). These authors assigned condition classes "...using natural breaks in the data."

\footnotetext{
Authors are research scientist, Wakwa Animal Research Center, P.O. Box 65 Ngaoundere, Cameroon; and professors of range science, New Mexico State University, Las Cruces 88003-0009. Journal article 1538 of the New Mexico Agricultural Experiment Station, Las Cruces 88003.

Experiment Station, Las Cruces 88003.
}

Australian workers have developed several approaches using various indices (Wilson and Tupper 1982) and more sophisticated analytical techniques (e.g. reciprocal averaging) (Hacker 1983). Other multivariate techniques have also been used to assist in the elucidation of range condition (Foran et al. 1986, Ratliff and Westfall 1987 and Uresk 1990).

In view of the wide range of approaches to range condition classification, the present study was conducted on a range site in southern New Mexico. Specific objectives were (1) to determine relationship between primary production and successional stage and (2) to compare the quantitative climax approach (Dyksterhuis 1949) with a multivariate technique for range condition classification.

\section{Study Area}

The study was conducted on the New Mexico State University College Ranch, about $35 \mathrm{~km}$ north of Las Cruces, New Mexico. The ranch lies in the southern portion of the Jornada del Muerto Plain, bordered by the Dona Ana Mountains on the southeast, the USDA Jornada Experimental Range and the San Andreas Mountains on the east, and the Rio Grande on the west. The ranch's topography is mostly flat to gently rolling, varying in elevation from 1,219 to $1,768 \mathrm{~m}$ above sea level.

Soils of the study area are within the Wink-Harrisburg association (SCS 1980). These soils are moderately coarse textured and fairly well drained. They vary considerably in depth.

The climate of the area is characterized by low rainfall, low humidity, high temperatures, high evaporation potential, and periodic strong winds. Average annual precipitation (1926-1986) on the New Mexico University College Ranch is $230 \mathrm{~mm}$. The major peak occurs during summer, which corresponds to the growing season for most $C_{4}$ herbaceous species, and a minor peak occurs in winter and supports some annual $C_{3}$ forbs. Daytime temperatures often exceed $30^{\circ} \mathrm{C}$ in summer, and freezing temperatures occur at night in winter.

Vegetation of the study areas is characteristic of the Chihuahuan Desert grassland formation (Humphrey 1958). Important grass species include black grama (Bouteloua eriopoda [Torr.]), mesa dropseed (Sporobolus flexuosus [Thurb.] Rybd.), and fluffgrass (Erioneuron puchellum [H.B.K.] Tateoka) on upland areas and tobosa (Hilaria mutica Buckl.]) on the lowland area. Creosotebush (Larrea tridentata [D.C.] Cov.) and mesquite (Prosopis glandulosa (SW) D.C.) are large shrubs, while broom snakeweed (Gutierrezia sarothrae [Pursh] Britt \& Rusby) is an abundant half-shrub.

\section{Methods and Procedures}

Standing crop data were obtained from 4 pastures involved in a grazing study on the New Mexico State University College Ranch (Beck 1978). A total of 120 transects were randomly located within blocks radiating concentrically out from permanent water points. Twenty $0.89-\mathrm{m}^{2}$ quadrats were systematically placed along each 61 $m$ transect. The average standing crop for each species in the quadrats on each transect was considered the experimental unit. Standing crop of each species was estimated in each quadrat by the weight-estimate method (Wilm et al. 1944).

The Soil Conservation Service (SCS) 1980 delineated 2 range 
Table 1. Average herbage production $\left(\mathrm{kg}_{\mathrm{g}} \cdot \mathrm{ha}^{-1}\right) \pm$ standard errors for various species when classified by the SCS and the cluster procedure.

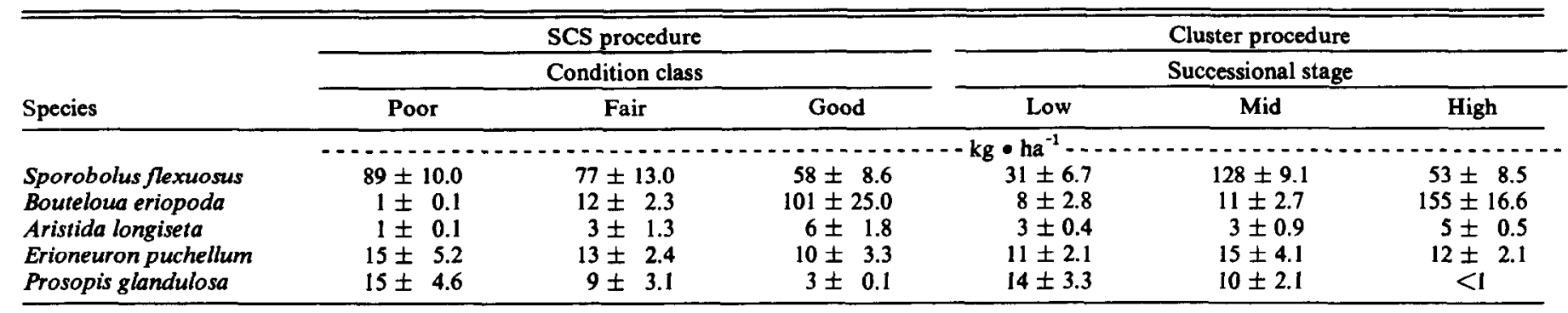

sites in the study pastures: the shallow range site and the sandy range site. Range condition of each transect in each range site was calculated following SCS (1980) procedures, based on perceived composition of climax communities. The 2 range sites are similar except for soil depth. In this study depth was also similar on the study locations.

Soil depth to an impervious layer for each transect was grouped into 1 of the following 3 classes: $0-25.4 \mathrm{~cm}$, very shallow; $25.4-50.8$ $\mathrm{cm}$, shallow; $50.8-101.6 \mathrm{~cm}$, moderately deep. In most cases, soil depth did not exceed $76 \mathrm{~cm}$. Distance of the transect to the nearest permanent water was also included in the analysis. These were the 2 abiotic factors included in the analysis.

Data from each transect were also subjected to cluster analysis (Orloci 1975). The flexible procedure with standard euclidian distance, $\beta=-0.25$, and was used in this study to group transects into different clusters. Multiple discriminant analysis was used on the groups derived from the SCS method and the cluster strategy to determine the efficiency of the 2 grouping procedures (Lindeman et al. 1980). This approach is similar to the one described by Ratliff and Westfall (1989).

Secondary successional patterns have been described for upland range sites in southern New Mexico (Gay 1965, McArdle and Costello 1936, Paulsen and Ares 1962). Climax conditions are represented by stands dominated by black grama (as much as $75 \%$ of plant cover). Seral stages are represented by less black grama cover and higher amounts of mesa dropseed, threeawns (Aristida spp.), and annuals. Low seral stages may be represented by mostly broom snakeweed and annuals (Gay 1965). Apparently vegetational changes within this general framework do occur, depending on climatic conditions and stocking rate (Paulsen and Ares 1962). Drought and heavy livestock grazing tend to decrease black grama abundance, while low grazing impact and high summer precipitation favors black grama (Nelson 1934, Nielson 1986, Paulsen and Ares 1962).

However, vegetational changes in the arid Southwest are often slow and erratic (Beck and Tober 1985, Herbel et al. 1972). When large shrubs such as mesquite and creosotebush become established on these upland sites, these successional stages may not apply, or at least the time frame must be altered. Perhaps some threshold has been exceeded to allow domination by large shrubs (Friedel 1988, Archer et al. 1988, Archer 1989). Domination by large shrubs would dramatically modify the successional pathways described.

\section{Results and Discussion}

\section{Primary Production}

Both the SCS procedure and the cluster analysis provided 3 groups that appeared to represent successional stages (Pamo 1983). These groupings were classified as good, fair, poor according to SCS procedures, and low, mid, and high seral stages for the cluster analysis procedure. According to the SCS procedure, only 1 transect was in excellent condition.

The cluster analysis provided groupings with a fairly uniform increase in total herbaceous standing crop from low-seral to highseral stages (Fig. 1). Differences between low and mid-seral stages was $107 \mathrm{~kg} \bullet \mathrm{ha}^{-1}$, while that between the mid and high-seral stage was $47 \mathrm{~kg} \cdot \mathrm{ha}^{-1}$. For the SCS procedure, there was no difference in total herbage standing crop between the poor and fair condition class (Fig. 1). Thus, it appears cluster analysis was more successful in separating the transects based on total biomass.

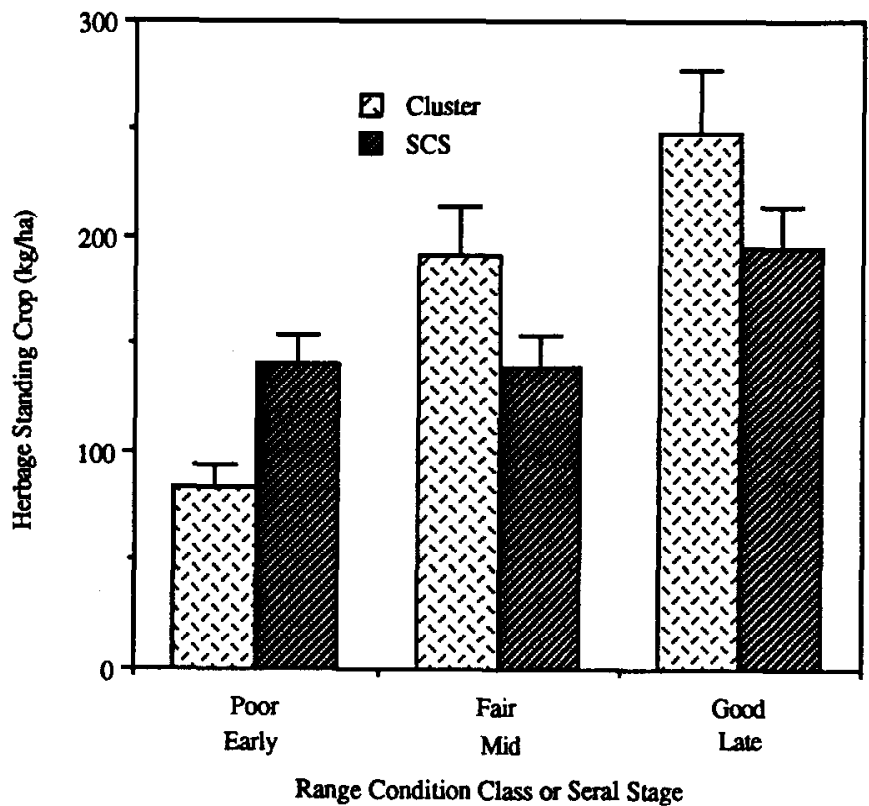

Fig. 1. Mean production for the 3 condition classes and the 3 seral stages of the 2 grouping procedure. Vertical bars represent standard errors.

There were also differences in the standing crop of the individual species for the 2 methods in the 3 groupings, especially for mesa dropseed (Table 1). Standing crop of mesa dropseed declined from good to poor condition class under the SCS procedure. However, mesa dropseed standing crop reached a peak in the mid-seral stage using the cluster procedure. These differences could have management implications if one wished to maximize black grama and mesa dropseed production. However, there is no objective means of deciding which analysis procedure follows successional patterns most faithfully. If production increases rather uniformly as secondary succession proceeds, the cluster procedure appears more satisfactory. Earlier research suggests that primary productivity is similar under conditions of adequate precipitation for different successional stages, but the proportion of perennial and annual plants differs (Pieper and Herbel 1982). In late-seral stages, perennial grasses dominate, while in early-seral stages, perennial grasses are fairly low in abundance; however, annuals such as Russian thistle (Salsola australis $R$. Brown) fill in the interspaces and contribute substantially to primary productivity. Neither procedure serves as a test of validity for the successional stages identi- 
fied. These must be evaluated by independent means (Pieper and Beck 1990). Recent interpretations indicate several stages are possible for a given site, and climatic fluctuations and grazing impacts may influence the transition from 1 stage to another (Westoby et al. 1989a, 1989b). A complete understanding of the ecological states for the area is important before any technique is applied to group similar communities or soil-vegetation complexes.

\section{Analysis of the Grouping Resulting from the SCS Method}

From the stepwise discriminant analysis, 7 variables (Table 2) were found to contain most of the classificatory information for the SCS grouping strategy. Multiple discriminant analysis for

Table 2. Stepwise discriminant analyses for SCS groupings. Stepwise selection:

\begin{tabular}{clcccc}
\hline \hline Step & Variable & $\begin{array}{c}\text { Order } \\
\text { entered } \\
\text { into model }\end{array}$ & $\begin{array}{c}\text { Partial } \\
\text { R }^{2}\end{array}$ & $\begin{array}{c}\text { F } \\
\text { statistic }\end{array}$ & $\begin{array}{c}\text { Prob> } \\
\text { F }\end{array}$ \\
\hline 1 & PCT BOER 1 & 1 & 0.5270 & 65.183 & 0.0001 \\
2 & ARLO.BOER & 2 & 0.1905 & 13.651 & 0.0001 \\
3 & Soil Depth & 3 & 0.1456 & 9.797 & 0.0001 \\
4 & SOIL DEPTH.BOER & 4 & 0.1014 & 6.430 & 0.0023 \\
5 & PRGL.SPFL & 5 & 0.0100 & 6.352 & 0.0024 \\
6 & ARLO.SPFL & 6 & 0.0625 & 3.734 & 0.0269 \\
7 & TOTL ARLO & 7 & 0.0521 & 3.051 & 0.0513 \\
\hline
\end{tabular}

1BOER = Boutelou a eriopoda $;$ ARLO = Aristida longiseta PRGL = Prosopis glandulosa; $\mathrm{SPFL}=$ Sporobolus flexuosus.

those variables chosen for the stepwise discriminant analysis showed the variability of these attributes was very large. The percentage biomass contribution of black grama increased from poor to good condition class. The mean soil depth was shallower in poor condition class, intermediate in the good condition class, and deepest in the fair condition class. However, these differences were not significant $(P>.05)$.

The percentage of black grama varied positively with soil depth in the poor condition class, but negatively with soil depth in the fair and good condition classes. The within-group correlation coefficients of the percentage black grama and soil depth was very low $(0.06)$ in the poor condition class and negative in both fair $(-0.12)$ and good $(-0.43)$ condition classes. The above results imply that as the soil depth increases, the percentage of black grama decreases. These results suggest that shallow soil maintains water within the reach of black grama roots while moisture is carried beyond the reach of black grama roots on the deep soil; thus the environment is not favorable for a maximum growth.

\section{Analysis of the Grouping Resulting from the Cluster Procedure}

The stepwise discriminant analysis identified 10 variables (Table 3 ) as the most important in the cluster grouping procedure. Soil depth was not selected as a discriminant criterion, suggesting it probably is not a reliable variable for site separation of these communities. Discriminant analysis of the selected variables was then investigated. The variability of those attributes was also large. The mean percentage of black grama was the least (1.19) in midseral stage, intermediate (1.61) in low-seral stage, and high (15.48) in late-seral stage (Table 1). However, the difference between the early and mid-seral stages was not significant. Total production consistently increased from early to late-seral stage.

\section{Comparison of the SCS Grouping Method to the Cluster Group- ing Strategy}

Internal analysis of each classification procedure (SCS method and cluster analysis), using discriminant analysis as a multivariate community comparison test, shows the equations derived from the SCS method did a relatively poor job of classifying the plant
Table 3. Stepwise discriminant analyses for SCS groupings. Stepwise selection:

\begin{tabular}{rlccrc}
\hline \hline & & $\begin{array}{c}\text { Order } \\
\text { entered } \\
\text { into model }\end{array}$ & $\begin{array}{c}\text { Partial } \\
\mathrm{R}^{2}\end{array}$ & $\begin{array}{c}\mathrm{F} \\
\text { statistic }\end{array}$ & $\begin{array}{c}\text { Prob }> \\
\text { F }\end{array}$ \\
\hline 1 & TOTL BOER 1 & 1 & 0.7213 & 151.434 & 0.0001 \\
2 & TOTL SPFL & 2 & 0.5284 & 64.976 & 0.0001 \\
3 & BOER SPFL & 3 & 0.3114 & 26.003 & 0.0001 \\
4 & BOER PRGL & 4 & 0.1525 & 10.258 & 0.0001 \\
5 & PCT BOER & 5 & 0.2081 & 14.846 & 0.0001 \\
6 & ARLO BOER & 6 & 0.1834 & 12.577 & 0.0001 \\
7 & SQPR ODTN & 7 & 0.1447 & 9.386 & 0.0002 \\
8 & TOTAL PRD & 8 & 0.1060 & 6.519 & 0.0021 \\
9 & BOER GUSA & 9 & 0.0530 & 3.049 & 0.0515 \\
10 & SPFL GUSA & 10 & 0.0453 & 2.563 & 0.0818 \\
\hline
\end{tabular}

${ }_{1}$ BOER = Bouteloua eriopoda $;$ SPFL $=$ Sporobolus flexuosus; PRGL $=$ Prosopis glanclulosa; $\mathrm{ARLO}=$ Aristida longise $a ; \mathrm{SQPR}$ ODTN $=$ Squared Production; $\mathrm{PRD}=$ Production; GUSA = Gutierrezia sarothrae.

communities of this portion of the College Ranch (Tables 4 and 5) because it does not predict accurately. Of 120 transects, 34(10+15 $+3+6$ ) or $28.33 \%$ were misclassified by the SCS method compared to only $7(5.83 \%)$ transects misclassified by the cluster procedure (Tables 4 and 5). Such results were not surprising because the SCS range site descriptions apply to large areas and were not developed specifically for range sites on the College Ranch.

Table 4. Discriminant analyses for variables chosen in stepwise discriminant analyses for SCS groupings.

\begin{tabular}{ccccc}
\hline \hline & \multicolumn{4}{c}{$\begin{array}{c}\text { Number of observations and percent classified } \\
\text { into groups based on } \\
\text { SCS procedure }\end{array}$} \\
$\begin{array}{c}\text { Discriminant } \\
\text { analysis }\end{array}$ & Poor & Fair & Good & Total \\
\hline 1 & 29 & 10 & 0 & 39 \\
& 74 & 26 & 00 & 100 \\
2 & 15 & 39 & 3 & 57 \\
& 26 & 68 & 5 & 100 \\
3 & 0 & 6 & 18 & 24 \\
& 0 & 25 & 75 & 100 \\
Total & 44 & 55 & 21 & 120 \\
Percentage & 37 & 46 & 18 & 100 \\
\hline
\end{tabular}

Table 5. Discriminant analyses for variables chosen in stepwise discriminant analyses for cluster groupings.

\begin{tabular}{ccccc}
\hline \hline & \multicolumn{5}{c}{$\begin{array}{c}\text { Number of observations and percent classified } \\
\text { into groups based on } \\
\text { cluster procedures }\end{array}$} \\
$\begin{array}{ccccc}\text { Discriminant } \\
\text { analysis }\end{array}$ & Early & Mid & Late & Total \\
\hline 1 & 49 & 3 & 0 & 52 \\
& 94 & 6 & 00 & 100 \\
2 & 4 & 50 & 0 & 54 \\
3 & 7 & 93 & 00 & 100 \\
& 0 & 0 & 14 & 14 \\
Total & 0 & 0 & 100 & 100 \\
Percentage & 53 & 53 & 14 & 120 \\
\hline
\end{tabular}

For the poor condition class and early-seral stage, neither procedure classified the same number of transects nor the same transects. The SCS method classified 39 transects in the poor condition class, while the cluster procedure classified 52 transects in the early-seral stage. Only 20 of the 39 transects of the SCS method were common to both classification procedures. Ten of 39 , 
or $25.7 \%$ were classified in fair condition by the multiple discriminant analysis. The cluster analysis in the early-seral stage was found to have misclassified only 3 transects, or $5.8 \%$ of the 52 . More realistically, this suggests the inadequacy of the classification scale (100-75, 75-50, 50-24, and 25-0). Also there are no substantial differences among the lower condition classes for the 2 sites. Different groupings are probably more realistic.

Many transects were grouped near the boundary between the poor and fair condition classes (Pamo 1983). Increasing the upper limit of the poor condition class to $30 \%$ of climax would include many transects classified in the low-seral stages by the cluster procedure. However, it would not completely solve the lack of correspondence between the 2 systems.

In the fair condition class and mid-seral stage, the number of transects classified by both procedures was relatively close: 57 by SCS methods and 54 by the cluster grouping procedure. The similarity of the transects in both procedures was still relatively low. There were 28 of the 57 or about $49 \%$ of the transects of the SCS procedure that were similar to both grouping strategies. The multiple discriminant analysis revealed that 18 transects were misclassified by the SCS method: 15 transects or $26 \%$ should have been classified in the poor condition class and 3 transects or $5 \%$ in the good condition class. The cluster procedure misclassified 4 transects (7\%). These transects should have been in the early-seral stage. Twenty-four transects were placed in the good condition class by the SCS grouping procedure and only 14 in the late-seral stage by the cluster analysis. Also, $54 \%$ of these transects were similar in both grouping methods. The cluster procedure did not misclassify any of the 14 transects. Six of the $24(25 \%)$ transects were misclassified in the good condition class by the SCS method. These transects should have been in the fair condition class.

The discriminant analysis indicates the cluster analysis is a relatively precise procedure in classifying these plant communities. Internally, the strategy provided equations that misclassified fewer transects than did the SCS method.

Discriminant analysis of the cluster grouping resulted in groupings that are the product of environmental variables and production. Cluster analysis, associated with multiple discriminant analysis using meaningful environmental variables, seems to be suitable for range site description and delineation in many rangelands where this type of information is needed.

The National Range Handbook (SCS 1976) points out that the range condition within a range site is determined by comparing the present plant community to the potential plant community, as indicated by the range condition guide for the site. For the existing plant community, no more than the maximum weight (or percentage of total production) shown on the guide for any species in the climax plant community can be included. The concept does not accommodate exotic species because they are not considered to be part of the climax vegetation (Smith 1978). A range site is the product of all environmental factors (climate, soils, and topography) responsible for its development. Sites are identified by evaluating and describing the distinctive climax plant communities that occur in an area. Large differences in species composition and productivity may require different management programs and, possibly indicate different sites. Data for range sites description is derived from many sources (Shiflet 1973):

1. Evaluation of relict (possibly climax) stands and associated soil on areas subjected to minimal abnormal disturbance.

2. Comparison of areas receiving varying degrees of use with similar areas receiving no use.

3. Evaluation and interpretation of research dealing with natural plant communities and soils.

4. Review of early historical and botanical literature.
5. Interpolation and extrapolation of existing vegetation information to areas of similar soils, climate, and micro environment, or along environmental gradients.

Sound management programs start with a thorough evaluation of current rangeland resources and their status. The SCS method cannot be applied directly in many world rangelands because the climax or potential plant communities are unknown or can only be determined at high cost. In addition, in the United States, present range site guides do recognize possible multiple states or common seral stages for 2 range sites (Huschle and Hironaka 1980). Cluster analysis has appeared to classify plant communities on the NMSU College Ranch in a relatively coherent manner. The method did not provide information on the potential plant communities to which we could compare the present communities and deduct the trend. Furthermore, it does not yield information on successional patterns and was not designed to do so. The technique, however, could provide a solid basis for a sound management program through the appropriate classification of existing vegetation on rangeland. These multivariate approaches, if carefully implemented, can provide the basis for a sustained development of rangeland resources within the framework of management goals (Foran et al. 1986). These methods, however, remain relatively complex in application and interpretation compared to the SCS procedure, and might be limited to agencies and specialists.

The SCS classification procedure does not provide a natural separation of seral plant communities as compared to the cluster procedure. Probably a successive modification of the SCS technique, if used to evaluate range condition and testing against the cluster analysis through trial and error could improve the SCS method. For management purposes, it does provide a framework for determining present status compared to a standard.

\section{Literature Cited}

Anderson, E.W. 1983. Ecological site/habitat type-a viewpoint. Rangelands. 5:187-188.

Archer, S., C.J. Scifres, and R. Maggio. 1988. Autogenic succession in a subtropical savanna: conversion of grassland to thorn woodland. Ecol. Monogr. 58:111-127.

Archer, S. 1989. Have southern Texas savannas been converted to woodlands in recent history. Amer. Natur. 134:545-561.

Beck, R.F. 1978. A grazing system for semiarid lands. pp. 569-572. In: Hyder, D.N. (Ed.). Proc. First Internat. Rangeland Congr.

Beck, R.F., and D.A. Tober. 1985. Vegetational changes on creosotebush sites after removal of shrubs, cattle, and rabbits. New Mex. State Univ. Agr. Exp. Sta. Bull. 717.

Bonham, C.D. 1983. Range vegetation classification. Rangelands. 5:19-21.

Daubenmire, R.F. 1984. Viewpoint: Ecological site/range site/habitat type. Rangelands. 6:263-264.

Dyksterhuis, E.J. 1949. Condition and management of rangeland based on quantitative ecology. J. Range Manage. 2:104-115.

Dyksterhuis, E.J. 1958. Ecological principles in range evaluation. Bot. Rev. 24:253-272.

Dyksterhuis, E.J. 1985. Follow-up on range sites and condition classes as based on quantitative ecology. Rangelands. 7:172-173.

Foran, B.D., G. Bastin, and K.A. Shaw. 1986. Range assessment and monitoring in arid lands: the use of classification and ordination in range survey. J. Environ. Manage. 22:67-84.

Hacker, R.B. 1983. Use of reciprocal averaging ordination for the study of range condition gradients. J. Range Manage. 36:25-30.

Hall, F.C. 1985. Viewpoint: The habitat type controversey; two common concepts. Rangelands. 7:170-171.

Herbel, C.H., F.N. Ares, and R.A. Wright. Drought effects on a semidesert grassland range. Ecol. 53:1084-1093.

Hofiman, G.R. 1984. Habitat types: a supportive view. Rangelands. 6:264-266.

Humphrey, R.R. 1947. Range forage evaluation by the range condition method J. Forest. 45:10-16.

Humphrey, R.R. 1949. Field comments on the range condition method of forage survey. J. Range Manage. 2:1-10.

Huschle, G., and M. Hironaka. 1980. Classification and ordination of seral plant communities. J. Range Manage. 33:179-182. 
Lauenroth, W.K., and W.A. Laycock (Eds.). 1989. Secondary succession and the evaluation of rangeland condition. Westview Press. Boulder, Colo.

Lindeman, R.H., P.F. Merendo, and R.L. Gold. 1980. Introduction to bivariate and multivariate analysis. Scott, Foresman and Co., Glenview, Ill.

Meeker, D.O., and D.L. Merkel. 1984. Climax theories and a recommendation for vegetation classification. J. Range Manage. 37:427-430.

Nielson, R.P. 1986. High-resolution climatic analysis and southwest biogeography. Science. 232:27-34.

Nieman, K.E., and M. Hironake. 1989. Soil-habitat type relationships: a theoretical model. In: Ferguson D.E., P. Morgan, F.D. Johnson (compilers). Proc. - Land classifications based on vegetation: applications for resource management. USDA Forest Serv. Gen. Tech. Rep. INT-257.

Orloci, L. 1975. Multivariate analysis in vegetation research. Dr. W. Junk Publ. The Hague.

Pamo, E.T. 1983. Mathematical approach to range condition in comparison to the SCS method. Ph.D. Diss. New Mex. State Univ., Las Cruces.

Paulsen, H.A., Jr., and F.N. Ares. 1962. Grazing values and management of black grama and tobosa grasslands and associated shrub ranges of the southwest. USDA Tech Bull. 1270.

Pieper, R.D., and C.H. Herbel. 1982. Herbage production and primary productivity of a desert grassland ecosystem. New Mexico State Univ. Agr. Exp. Sta. Bull. 695.

Pieper, R.D., and R.F. Beck. 1990. Range condition analysis: modifications to meet multiple use objectives. J. Range Manage. 43:550-552.

Ratliff, R.D., and R.D. Pieper. 1982. Approaches to plant community classification for the range manager. JRM Monograph. Ser. No. 1. Soc. Range Manage., Denver, Colo.
Ratliff, R.D., and S.E. Westfall. 1989. Monitoring plant community change: an application of quadrat classification and discriminant analysis. Vegetatio 80:1-9.

Ratlif, R.D., and S.E. Westfall. 1990. Classifying and monitoring Carex exserta meadows in California's Sierra Nevada. In press.

Smith, E.L. 1979. Evaluation of the range condition concept. Rangelands. 1:52-54.

Soil Conservation Service. 1980. Soil Survey of Dona Ana County Area, New Mexico. Gov. Print. Office, Wash. D.C.

Soil Conservation Service. 1980. Technical range site description guide. New Mexico State Office, SCS, Albuquerque, N Mex.

Tueller, Paul T., and W.H. Blackburn. 1974. Condition and trend of the big sagebrush/needle and thread habitat type in Nevada. J. Range Manage. 27:36-40.

Uresk, D.W.1990. Using multivariate techniques to quantitatively estimate ecological stages in a mixed grass prairie. J. Range Manage. 43:282-285.

U.S. Dep. Agriculture. 1980. The Jornada Experimental Range. USDA, Las Cruces, N. Mex.

Westoby, M., B. Walker, and I. Noy-Meir. 1989. Range management on the basis of a model which does not seek to establish equilibrium. J. Arid. Environ. 17:235-239.

Westoby, M., B. Walker, and I. Noy-Meir. 1989. Opportunistic management for rangelands not at equilibrium. J. Range Manage. 42:266-274.

Wilm, H.G., D.F. Costello, and G.E. Klipple. 1944. Estimating forage yield by the double sampling method. J. Amer. Soc. Agron. 36:194-203. 